\title{
Egg shortage hits race to clone human stem cells
}

US stem-cell researchers are calling for changes to state laws that prohibit compensating women who donate eggs for research. The laws, in leading stem-cell research states such as Massachusetts and California, are crippling the promising field of 'therapeutic cloning' that could produce useful embryonic stem-cell lines for studying various human diseases, they say.

Therapeutic cloning involves transferring the nucleus from an adult human cell into a human egg with the intent of creating stem cells from the resulting embryo. Such cells could potentially serve as a therapy genetically matched to the person who donated the adult cell. Although no one has yet derived these cells, one group has now reported creating cloned human embryos in this way. But the procedure uses many eggs. Researchers say that because many states do not allow women to be paid for their egg donation, potential donors are put off and choose lucrative fertility clinics instead.

It took Kevin Eggan and Douglas Melton, of Harvard University's Stem Cell Institute, two years and US\$100,000 in local advertising to secure a single egg donor (see 'How close, how comfortable?') for their attempt to develop embryonic stem-cell lines to model diseases such as amyotrophic lateral sclerosis. The group, which obtained fewer than ten eggs, completed its experiments early this year, Eggan announced last month at a meeting of the Society for the Study of Reproduction in Kona, Hawaii. They are not yet ready to discuss results.

Eggan says that although Harvard's highly publicized egg-donation programme received plenty of responses, many women decided against donating for research when they were informed that a fertility clinic would compensate them for the same procedure. The extraordinary efforts needed to recruit donors such as this "unique woman" would not be required, says Eggan, if rules restricting the compensation of donors were relaxed.

Fertility clinics in the United States are allowed to pay for eggs. Some advertise remuneration in the tens of thousands of dollars. "It's patently unfair," says Sam Wood, head of Stemagen, a biotech company based in La Jolla, California, which uses eggs leftover from fertility procedures at an associated clinic. In January, Wood's team reported the first cloned human blastocysts. These earlystage embryos were created from 29 egg cells retrieved from three donors (A. J. French et al. Stem Cells 26, 485-493; 2008).

Stemagen attains the consent of both donor and recipient, but offers no compensation beyond that offered for the reproductive egg donation. This 'uncompensated shared cycle donation', model has "worked quite well”, Wood says, but a compensation model would be fairer to donors. "For virtually any other type of biomedical research you are allowed to compensate fairly."

US regulations vary from state to state New York is currently debating its laws on egg payment. Some states allow for reimbursement of lost wages, expenses or child care during the

\section{How close, how comfortable?}

She has chosen to remain anonymous, but the one egg donor acquired by Kevin Eggan's group at Harvard University has unspecified ties to Harvard.

It's fact that calls to mind the looming spectre of disgraced Korean cloner Woo Suk Hwang, whose fall was precipitated not just by his fraudulent research, but his ethically questionable use of eggs donated by members of his lab.

However, although Eggan's research protocol did not preclude such donors, his team agreed to avoid such conflicts. "The first questions that came out of my mouth," says Eggan, "were 'Does she work in my lab or my department?"' The answer was no.

Eggan has never met the donor, who could be any age between 25 and 35 according to the study's inclusion criteria, and he says he only found out about the Harvard connection when inquiring about her motivations. Alta Charo, a lawyer and bioethicist at the University of Wisconsin Law School in Madison, says this shouldn't pose a problem: "If the donor was an employee or under direct supervision of the team doing the research, it would suggest that there is a risk that this was not a completely voluntary source.

"But if she was someone who teaches there, goes to school there, or works in a completely different setting, I don't see that there would be an issue there at all." procedure, which can take 60 hours, including initial screening, consultations, hormone injection and surgical removal of oocytes. Other countries, including the United Kingdom, allow compensation in different forms, such as offsetting the costs of fertility treatment in return for research material.

The US National Academy of Sciences (NAS) guidelines barring compensation were set in part to protect poor people from being exploited by labs that might offer large sums of money - along the lines of rules barring compensation for organ donation. But Alta Charo, a lawyer and bioethicist at the University of Wisconsin Law School in Madison, who liaised with the NAS committee that set donor-compensation guidelines in 2005 , says the move was as much political as ethical. In California, supporters of Proposition 71, which allows funding for stem-cell and cloning research in the absence of federal funding, adopted compensation prohibition in part, Charo claims, "to assuage a fringe group of the women's movement" that was aligned against the assisted-reproduction community.

The NAS guidelines followed the lead taken by California and some countries to ensure that stem cells could easily cross state and international borders. The United Kingdom, however, essentially changed the rules two years ago. In 2006, Alison Murdoch of Newcastle University received approval for a plan to allow couples to defray the costs of fertility treatments if they are willing to share some eggs for research purposes. This could create disparity in the quality of care available to people who don't have the money to undergo fertility treatments, says 


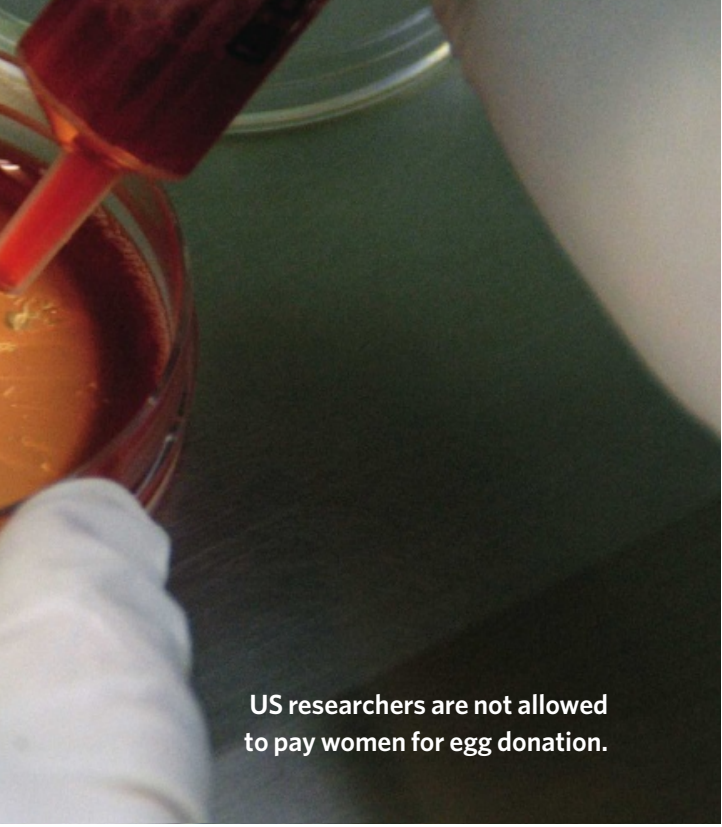

Charo, but it could also provide access to such treatments for more people. Murdoch has so far collected more than 100 eggs in this fashion.

Wood says that this egg-sharing workaround presents a problem; the eggs being used for research are from older individuals, presumably with fertility problems. Using eggs donated by women aged 20-24, he has reportedly achieved cloning success rates near 25\%.

And there are ethical concerns. Marcy Darnovsky of the Center for Genetics and Society in Oakland, California, says that such schemes split the doctor's duty of care three ways: between donor, fertility patient and researchers. And the focus on compensation, she says, distracts from concerns about risks from this one research avenue when other avenues seem open.

Even in light of rapid advancement of induced pluripotent stem cells - embryonic stem cell-like cells created by adding specific genes to adult cells - research using human eggs to reprogramme the nucleus continues, and with some success. Wood says Stemagen's work has been advancing rapidly. Eggan's group, while waiting for fresh eggs, showed that in principle unfertilized eggs could be obviated by introducing a nucleus into an already fertilized egg (D. Egli et al. Nature 447, 679-685; 2007), which might be easier to obtain.

Still, Eggan says, his group's first modest attempts with unfertilized human eggs are more compelling. "Our results confirm, for us, that the best way to do the experiments is with unfertilized oocytes. That said, it doesn't seem like we're going to be getting many of those any time soon."

Brendan Maher

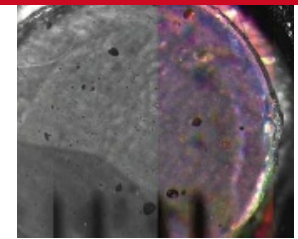

DASTARDLY DANDRUFF

Skin flakes could scupper Phoenix Mars mission.

www.nature.com/news

\section{Fusion reactor faces cost hike}

A massive international nuclear fusion experiment planned for Cadarache, France, is set to cost up to $30 \%$ more than anticipated and be delayed by as much as three years, governments will learn next week.

Construction has not even begun on the ITER fusion reactor, which has been beset by political wrangling since its inception. Now its seven international backers are to be told they will have to come up with an extra $€ 1.2$ billion-1.6 billion (US $\$ 1.9$ billion-2.5 billion) on top of its current $€ 5$-billion construction budget if the project is to be realized.

A report from a group of scientific advisers says the additional money is needed for critical design changes and for coordinating between the participant nations. And the experiment, already delayed, will not be completed until anywhere from one to three years after its current 2016 due date.

Critics expect more cost hikes. "Personally, I think the price will double before it's done," says Stephen Dean, president of Fusion Power Associates, based in Gaithersburg, Maryland.

But ITER officials maintain that the new budget and schedule are achievable and that the review could not have come sooner because the ITER organization was only formed in 2006. "A good, rigorous review could only be done now," says Neil Calder, a spokesman for the project.

ITER is designed to test the feasibility of fusion power. The machine will trap hydrogen isotopes in magnetic fields and heat them to around 100 million Celsius. At that temperature, the hydrogen will fuse to form helium, releasing neutrons and energy in the process. If it works, it a research and educational foundation could lead to a second major source of atomic energy besides fission.

The project was originally proposed as a US-Soviet collaboration in the mid-1980s. It has since added partners including the European Union, South Korea, Japan, China and India, and was redesigned in the late 1990s to make it smaller and cheaper.

When ITER was finalized in mid-2005, its anticipated budget was $€ 10$ billion over 30 years, with half of that going to construction (see Nature 435, 1142; 2005). Dean says that estimate was based on an incomplete design and that "some things were not looked at in detail".

Over the past two years, scientists and engineers have been reworking the design. Researchers now want to add magnets to control a newly discovered instability (see Nature 452, 11; 2008). Buildings at Cadarache will have to be made earthquake-proof, something not included in the original blueprints because the site was undecided. And the addition of latecomers such as India and China will increase its overheads.

The new price tag must be approved by the ITER council, which oversees the project. "For all members, the cost issue is very sensitive," says one Japanese government official familiar with the project. The changes will be presented on 17-18 June at a meeting in Aomori Prefecture in Japan, and a new budget decided at meeting in November.

Dean anticipates that the new budget will ultimately be approved. "This thing has gotten a life of its own - it's almost irrelevant how much it costs or what it's for."

Geoff Brumfiel

See Editorial, page 824

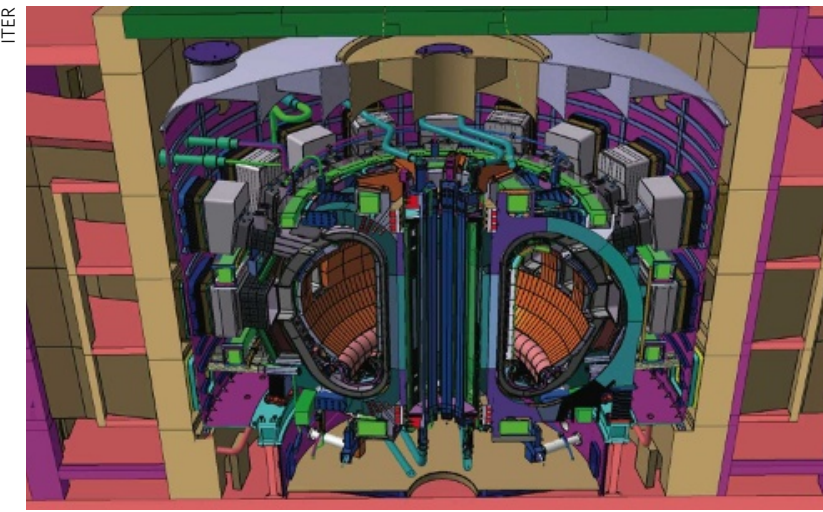

Money to burn: Extra magnets and earthquake protection are some of the factors making ITER more expensive. 